Gut, 1984, 25, 644-648

\title{
Increased concanavalin A induced suppression in treated and untreated coeliac disease
}

\author{
CLIONA O'FARRELLY, U McKEEVER, C FEIGHERY, AND D G WEIR \\ From the Departments of Immunology and Clinical Medicine, Trinity College, Dublin; and St James's \\ Hospital, Dublin
}

SUMMARY The generation of suppression by concanavalin A in peripheral blood mononuclear cells in treated and untreated coeliac subjects using an in vitro assay was found to be significantly increased when compared with controls. The response of peripheral blood mononuclear cells to the plant mitogen concanavalin A (con A) was also significantly depressed in both groups of coeliac patients. It is proposed that the depressed cell mediated immunity found in this and other studies in coeliac patients is because of increased suppression. The possible connection between these findings and the increased incidence of malignancy also found in coeliac disease is discussed.

An association between coeliac disease and intestinal malignancy was recognised in the $30 \mathrm{~s}^{12}$ and subsequently confirmed. ${ }^{3-6}$ It was then suggested that intestinal malignancy was a complication rather than a coincidental association with coeliac disease. ${ }^{7}$ This was confirmed by statistical analysis of studies on larger series ${ }^{89}$ which indicated that there might be a similar mechanism underlying both pathologies.

An immunoregulatory abnormality could be responsible for both the malignancy and the depressed cell mediated immunity seen in malignant states and diseases of unknown aetiology such as Hodgkin's disease, systemic lupus erythematosus and coeliac disease. ${ }^{10}$ Depressed immunity in coeliac disease is suggested by lymphoreticular atrophy ${ }^{11}$ and depressed lymphocyte transformation. ${ }^{12} 13$ In addition, it has been shown that lymphocytes from patients with coeliac disease have a significantly reduced proliferative and cytotoxic capacity when challenged in vitro with tumour cells from a lymphoma cell line as compared with normal lymphocytes. ${ }^{14}$

Depressed cell mediated immunity in Hodgkin's disease has been shown to be caused by increased suppression. ${ }^{15} \mathrm{~A}$ helper cell defect has been found in systemic lupus erythematosus. ${ }^{16}$ Thus, it appears that abnormalities of the immunoregulatory system

Address for correspondence: Dr Cliona O'Farrelly, Immunology Department, Central Pathology Laboratory, St James's Hospital, Dublin 8, Eire.

Received for publication 12 August 1983 are important in the pathogenesis of a number of disorders and may be of significance in coeliac disease.

The purpose of this study was to confirm the observation that cell mediated immunity is depressed in coeliac disease using a lymphocyte transformation assay. An in vitro assay of the generation of suppression was used to examine the hypothesis that an immunoregulatory abnormality is responsible for the depressed cellular immunity and the increased incidence of malignancy associated with coeliac disease.

\section{Methods}

MATERIALS

PREPARATION OF PERIPHERAL BLOOD

MONONUCLEAR CELLS

Venous blood was collected into tubes containing preservative-free heparin. Blood was mixed with an equal volume of Hank's balanced salt solution and layered onto Ficoll-hypaque gradients. After centrifugation at $500 \mathrm{~g}$ for 30 minutes, the cells at the interface were removed and washed three times with Hank's balanced salt solution containing $50 \mu \mathrm{g}$ of gentamycin per $\mathrm{ml}$ and $10 \mathrm{mM}$ Hepes buffer $\mathrm{pH}$ $7 \cdot 3$.

PREPARATION OF MITOGEN

Concanavalin A (con A) was dissolved in Hank's balanced salt solution and then sterilised by filtration using a $0 \cdot 22 \mu \mathrm{m}$ filter. Stock solutions were made and stored in $1 \mathrm{ml}$ aliquots at $-20^{\circ} \mathrm{C}$. On the 
day of use, working solutions of 10, 20) and $50 \mu \mathrm{g} / \mathrm{ml}$ were made up in Hank's balanced salt solution.

\section{LYMPHOCYTE TRANSFORMATION}

Peripheral blood mononuclear cells were suspended in RPMI 1640 containing $10 \%$ fetal calf serum and $50 \mu \mathrm{g} / \mathrm{ml}$ gentamycin at a concentration of $1 \times 10^{\mathrm{h}}$ cells $/ \mathrm{ml}$. Aliquots of $200 \mu \mathrm{l}$ were added to the wells of microculture plates, covered and incubated at $37^{\circ} \mathrm{C}$ with $5 \% \mathrm{CO}_{2}$ and $95 \%$ humidity. Cells were grown with or without con $\mathrm{A}$ at final concentrations of 1,2 and $5 \mu \mathrm{g} / \mathrm{ml}$ and each culture was carried out in triplicate.

\section{GENERATION OF SUPPRESSION}

Suppressor cell activity was shown by the technique previously used in this laboratory. ${ }^{17}$ Aliquots of $4 \times 10^{6}$ peripheral blood mononuclear cells were precultured in RPMI at a concentration of $2 \times 10^{6}$ cells $/ \mathrm{ml}$. Con A $(5 \mu \mathrm{g} / \mathrm{ml})$ was added to the test cells and no stimulant was added to control cells. After 24 hours incubation, the cells were washed twice in Hank's balanced salt solution and resuspended in RPMI containing $50 \mu \mathrm{g} / \mathrm{ml}$ of mitomycin C. After incubation for one hour at $37^{\circ} \mathrm{C}$ in $5 \% \mathrm{CO}_{2}$ and $95 \%$ humidity, the cells were again washed three times with Hank's balanced salt solution. The concentration of each group of cells was then adjusted to $1 \times 10^{6} \mathrm{cells} / \mathrm{ml}$ and dispensed in $100 \mu \mathrm{l}$ aliquots into the wells of microculture plates. Equal volumes of autologous peripheral blood mononuclear cells (responders) also at a concentration of $1 \times 10^{6}$ cells $/ \mathrm{ml}$, which had been maintained in RPMI at $37^{\circ} \mathrm{C}$ in $5 \% \mathrm{CO}_{2}$ for 24 hours, were added to the mitomycin $\mathrm{C}$ treated cells (stimulators). The cocultured cells were or were not stimulated with 1 , 2 or $5 \mu \mathrm{g} / \mathrm{ml}$ of con A. Each test was carried out in triplicate and cultured for 72 hours.

\section{TERMINATION OF CULTURES}

Twenty four hours before harvesting, $0.3 \mu \mathrm{Ci}$ of ${ }^{3} \mathrm{H}$ thymidine (sp.act: $2.0 \mathrm{mCi} / \mathrm{ml}$ ) was added to each well. At the end of the 72 hour incubation period, the cells were washed onto glass fibre discs using an automatic cell harvester. The discs were suspended in a scintillation cocktail and the amount of cellincorporated ${ }^{3} \mathrm{H}$ thymidine was measured in a scintillation counter.

\section{CALCULATION OF PERCENTAGE SUPPRESSION}

The percentage of enhancement or suppression of response to con $\mathrm{A}$ by the responders was calculated using the following formula:

$$
1-\left[\frac{\left(\mathrm{CM}^{\mathrm{ca}}-\mathrm{C}^{\mathrm{ca}}\right)}{(\mathrm{CM}-\mathrm{C})}\right] \times 100 \%
$$

where $\mathrm{CM}^{\text {ca }}$ represents counts per minute of peripheral blood mononuclear cells precultured in the presence of con $A$, mitomycin $C$ treated and added to autologous peripheral blood mononuclear cells in the presence of con $A$; $C^{\mathrm{ca}}$ is counts per minute of peripheral blood mononuclear cells precultured in the presence of con $\mathrm{A}$, mitomycin $\mathrm{C}$ treated and added to autologous peripheral blood mononuclear cells in the absence of con $\mathrm{A}$; $\mathrm{CM}$ is counts per minute of peripheral blood mononuclear cells precultured in the absence of con $\mathrm{A}$, mitomycin $C$ treated and added to autologous peripheral blood mononuclear cells in the presence of con $A$; $C$ is counts per minute of peripheral blood mononuclear cells precultured in the absence of con A, mitomycin $C$ treated and added to autologous peripheral blood mononuclear cells in the absence of con $\mathrm{A}$.

\section{SUBJECTS}

Forty three patients with adult coeliac disease of whom 32 were women, were studied. Ages ranged from 18-66 years with a mean of 28 years. Twenty eight were on gluten free diets and 15 were untreated when tested. All had the characteristic lesion of coeliac disease on jejunal biopsy and a clinical response to the diet of at least six months in the treated patients. The subsequent clinical response of the untreated group to gluten withdrawal confirmed the diagnosis. Twenty of the 43 patients were rebiopsied post treatment and all showed histological improvement in response to the gluten free diet. A control group of 31 normal individuals was also studied.

\section{STATISTICS}

The Wilcoxon's test was used to analyse the results.

\section{Results}

LYMPHOCYTE TRANSFORMATION (FIG. 1)

The response of untreated coeliac peripheral blood mononuclear cells was significantly depressed when compared with normal peripheral blood mononuclear cells at $5 \mu \mathrm{g} / \mathrm{ml}$ of con A p $<0.01$ and at $2 \mu \mathrm{g} / \mathrm{ml}$ of con A p $<0.01$. At the $1 \mu \mathrm{g} / \mathrm{ml}$ dose of con $A$, the respective mean values of the untreated group and the normal group were also significantly different $(p<0.01)$. The response of treated coeliac peripheral blood mononuclear cells to $5 \mu \mathrm{g} / \mathrm{ml}$ and $2 \mu \mathrm{g} / \mathrm{ml}$ of con A was also significantly depressed when compared with the normal group $p<0.01$. At $1 \mu \mathrm{g} / \mathrm{ml}$ con $A$ the mean response of the treated coeliac group was depressed but not significantly so. There was no significant difference between the treated and untreated coeliac groups at any of the three doses of con A. 


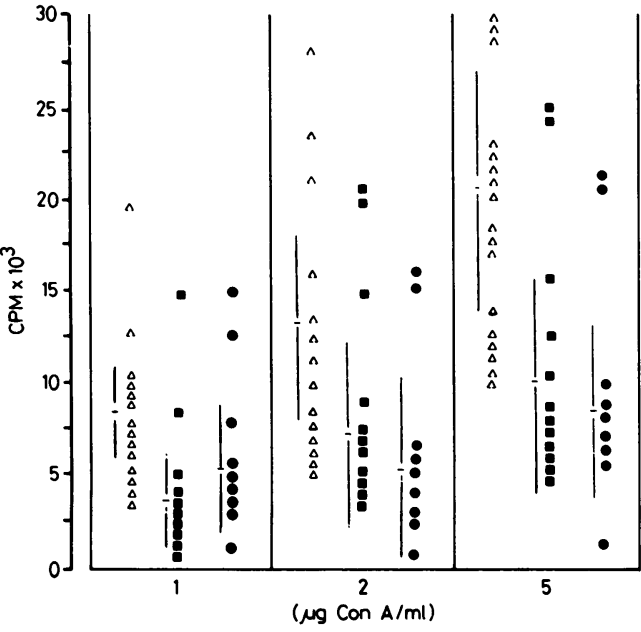

Fig. 1 Lymphocyte transformation in normal subjects $(\Delta)$, untreated $(\square)$ and treated $(O)$ coeliac patients. Horizontal bars represent means and vertical lines represent one standard deviation.

GENERATION OF SUPPRESSION (FIG. 2)

The mean level of suppression generated by con $A$ in peripheral blood mononuclear cells from untreated coeliac patients was significantly higher than that generated in normal peripheral blood mononuclear cells at $5 \mu \mathrm{g} / \mathrm{ml}$ of con A $(\mathrm{p}<0.001)$

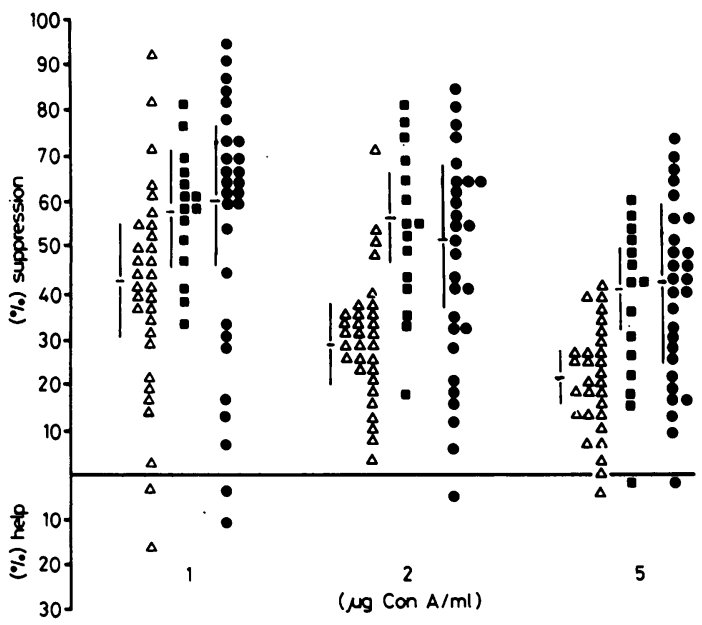

Fig. 2 Percentage suppression in normal subjects $(\Delta)$ untreated $(\boldsymbol{D})$ and treated coeliac patients $(\mathbf{O})$. Horizontal bars represent means and vertical lines represent one standard deviation. and at $2 \mu \mathrm{g} / \mathrm{ml}$ con $\mathrm{A}(\mathrm{p}<0 \cdot 01)$. The difference at the $1 \mu \mathrm{g} / \mathrm{ml}$ dose of con A was not significant.

In treated coeliac peripheral blood mononuclear cells, the mean level of suppression was significantly higher than in normal peripheral blood mononuclear cells at $5 \mu \mathrm{g} / \mathrm{ml}$ con A p $<0.001$, at $2 \mu \mathrm{g} / \mathrm{ml}$ con $A$, and the $1 \mu \mathrm{g} / \mathrm{ml}$ dose of con $A \mathrm{p}<0.01$.

There was no significant difference between the degrees of suppression in the treated and untreated coeliac groups.

\section{Discussion}

This study confirms that peripheral blood mononuclear cell proliferation in response to stimulation by plant mitogens is depressed in treated and untreated coeliac patients. A possible cause for the depressed cell mediated immunity in coeliac disease is nutritional deficiency consequent upon malabsorption, as cell mediated immunity is known to be depressed in severe malnutrition. ${ }^{18} 19$ Twenty coeliac patients who were on a gluten-free diet and had shown a complete clinical recovery and histological improvement also showed depressed cell mediated immunity.

Changes in cell mediated immunity in coeliac disease could be secondary to alteration of lymphocyte subpopulations known to occur in this disease. Both the proportion and absolute numbers of circulating thymus dependent lymphocytes are reduced in untreated coeliac disease. ${ }^{20}$ This depletion may be because of impaired production, increased sequestration in lymphoreticular tissue, or excessive loss into the gut lumen. $T$ cell numbers return to normal, however, after dietary treatment $^{2021}$ whereas this study suggests that the response of coeliac peripheral blood mononuclear cells remains depressed even after treatment.

Control of the immune response is affected by regulatory cells having suppressive or enhancing influences, ${ }^{22} 23$ the net reactivity representing the balance between the two forces. Excessive suppression has been reported in hypogammaglobulinaemia $^{24}$ and multiple myeloma. ${ }^{25}$ The results presented here indicate that peripheral blood mononuclear cells from treated and untreated coeliac patients have increased suppressive ability when compared with normal controls. Such a disturbance of immune response regulation may be responsible for the depressed cell mediated immunity and could be of pathogenic significance.

Previous investigators have used the short lived suppressor cell assay of Bresnihan and $\mathrm{Jasin}^{26}$ to study immunoregulation in coeliac patients. ${ }^{27}$ It was concluded that a suppressor cell deficiency was present in the disease population. The correct 
interpretation of this assay is disputed, however, as it is possible that the altered responsiveness of 24 hour pre-incubated peripheral blood mononuclear cells may reflect decreased prostaglandin activity ${ }^{28}$ and not necessarily the loss of suppressor cells. On the other hand, the assay described by Shou and colleagues in which suppressor-cell activity is induced by con $A$ is a system by which the generation of suppression can be measured.$^{29}$ It is, therefore, a useful technique for examining immunoregulation in disease states.

Normal lymphocytes have a surveillance function which is responsible for the recognition and elimination of mutant neoplastic cells in the body. ${ }^{30}$ Patients with immune deficiencies are known to have an increased risk of malignancy, ${ }^{31}$ possibly caused by abnormality of immunosurveillance. The depressed cellular immunity and increased suppression seen in this study in coeliac disease could reflect a defect in immunoregulation in vivo which may be responsible for the increased incidence of malignancy in coeliac disease. The results presented here also indicate that the immunoregulatory abnormality is not altered by dietary treatment. In a recent study, when coeliac patients with and without lymphoma were compared, no significant differences were seen between those with histological improvement on the gluten free diet, those who failed to show improvement and those in whom no follow up biopsies were done. ${ }^{32}$

Increased numbers of suppressor cells have been seen in the peripheral blood of patients with pulmonary sarcoidosis. ${ }^{33}$ These cells could be responsible for the anergy described in in vitro studies of blood $T$ cells from patients with this disorder. ${ }^{34}{ }^{35}$ The ratio of helper to suppressor cells is significantly raised in the lungs of sarcoid patients, ${ }^{33}$ suggesting that the lung helper cells are derived from the peripheral blood resulting in a depletion of peripheral blood helper cells. Increased suppression and depressed cell-mediated immunity in peripheral blood mononuclear cells and increased helper cells from the disease site have been found in Crohn's disease, indicating a similar pathogenic pattern. ${ }^{36}$ Studies on coeliac disease have shown that the immune system is hyperactive in the gut, indicating a possible increase in helper cell activity $^{37-40}$ while the results of this study show increased suppression in the peripheral blood. These findings suggest that there is a common pattern in the distribution of regulatory lymphocytes in a number of immunologically mediated disorders which may be of pathological significance.

We are grateful to the Medical Research Council of Ireland and to the Provost's Appeal Fund, Trinity
College, Dublin for financial support during this project.

\section{References}

1 Golden R. The small intestine and diarrhoea. AJR. 1936; 36: 892-901.

2 Fairley NH, Mackie FP. The clinical and biochemical syndrome in lymphadenoma and allied diseases involving mesenteric lymph nodes. Br Med J 1937; 1: 375-80.

3 Harrison HE, Harrison HC, Tompsett RR, Barr DP. Potassium deficiency in a case of lymphosarcoma with the sprue syndrome. Am J Med 1947; 2: 131-43.

4 Sleisenger MH, Almy TP, Barr DP. The sprue syndrome secondary to lymphoma of the small bowel. Am J Med 1953; 15: 666-74.

5 Friedlander PH, Gorvy V. Steatorrhoea. Br Med J 1955; 2: 809-12.

6 Best CN, Cook PB. Case of mesenteric reticulosarcoma associated with gluten-sensitive steatorrhoea. Br Med J 1961; 2: 496-8.

7 Gough KR, Read AE, Naish JM. Intestinal reticulosis as a complication of idiopathic steatorrhoea. Gut 1962; 3: 232-9.

8 Austad WI, Cornes JS, Gough KR, McCarthy CF, Read AE. Steatorrhoea and malignant lymphoma: the relationship of malignant tumours of lymphoid tissue and coeliac disease. Am J Dig Dis 1967; 12: 475-90.

9 Harris OD, Cooke WT, Thompson H, Waterhouse JAH. Malignancy in adult coeliac disease and idiopathic steatorrhoea. Am J Med 1967; 42: 899-912.

10 Burnet FM. A modern basis for pathology. Lancet 1967; 1: 1383-7.

11 McCarthy CF, Fraser ID, Evans KT, Read AE. Lymphoreticular dysfunction in idiopathic steatorrhoea. Gut 1966; 7: 140-5.

12 Morganroth J, Watson DW, French AB. Cellular and humoral sensitivity to gluten fractions in patients with treated non-tropical sprue. Am J Dig Dis 1972; 17: 205-12.

13 Scott BB, Losowsky MS. Depressed cell-mediated immunity in coeliac disease. Gut 1976; 17: 900-5.

14 Maclaurin BP, Cooke WT, Ling NR. Impaired lymphocyte reactivity against tumour cells in patients with coeliac disease. Gut 1971; 12: 794-800.

15 Twomey JJ, Laughter AH, Farrow S, Douglas CC. Hodgkins disease. An immuno-depleting and immunosuppressive disorder. J Clin Invest 1975; 56: 467-75.

16 Delfraissy JF, Segond P, Galanaud P, Wallon C, Massias $\mathrm{P}$, Dormont $\mathrm{J}$. Depressed primary in vitro antibody response in untreated SLE. $T$ helper cell defect and lack of defective suppressor cell function. J Clin Invest 1980; 66: 141-8.

17 Feighery C, Whelan CA, Weir DG, Greally JF. In vitro studies of suppressor cell function in human peripheral blood mononuclear cells. Clin Exp Immunol 1978; 32: 459-65. 
18 Geefhuysen J, Rosen EU, Katz J, Ipp T, Metz J. Impaired cell-mediated immunity in kwashiorkor with improvement after therapy. Br Med J 1971; 4: 527-9.

19 Smythe PM, Schonland M, Brereton-Stiles GG et al. Thymolymphatic deficiency and depression of cellmediated immunity in protein-calorie malnutrition. Lancet 1971; 2: 939-44.

20 O'Donoghue DP, Lancaster-Smith M, Laviniere P, Kumar P. T-cell depletion in untreated adult coeliac disease. Gut 1976; 17: 328-33.

21 Bullen AW, Losowsky MS. Lymphocyte subpopulations in adult coeliac disease. Gut 1978; 19: 892-7.

22 Baker PG. Homeostatic control of antibody responses: a model based on the recognition of cell-associated antibody by regulatory T cells. Transplant Rev 1975; 26: 4-32.

23 Dutton RW. Suppressor T cells. Transplant Rev 1975; 26: 39-51.

24 Waldman TA, Durm M, Broder S, Blackman M, Blaese RM, Strober W. Role of suppressor T cells in pathogenesis of common variable hypogammaglobulinaemia. Lancet 1974; 2: 609-11.

25 Broder S, Humphrey R, Durm M et al. Impaired synthesis of polyclonal (non-paraprotein) immunoglobulins by circulating lymphocytes from patients with multiple myeloma. $N$ Engl J Med 1975; 293: 887-93.

26 Bresnihan B, Jasin HE. Suppressor function of peripheral blood mononuclear cells in normal individuals and in patients with systemic lupus erythematosus. J Clin Invest 1977; 59: 106.

27 Robertson DAF, Bullen A, Field H, Simpson FG, Losowsky MS. Suppressor cell activity, splenic function and HLA B8 status in man. J Clin Lab Immunol 1982; 9: $133-8$.

28 Bray M. Prostaglandins: fine tuning the immune system? Immunology Today 1980; 1: 65-9.

29 Shou L, Schwartz S, Good RA. Suppressor cell activity after concanavalin A treatment of lymphocytes from normal donors. $J$ Exp Med 1976; 43: 1100-10.
30 Baldwin RW, Robbins RA. Induction of tumour immune responses and their interaction with the developing tumour. Contemp Top Mol Immunol 1977; 6: 177.

31 Amman AJ, Fudenberg HH. Immunodeficiency diseases. In: Fudenberg HH, Stites DP, Caldwell JL, Wells JV, eds. Basic and clinical immunology. MP: Los Altos, 1980: 407.

32 Swinson CM, Slavin G, Coles EC, Booth CC. Coeliac disease and malignancy. Lancet 1983; 1: 111.

33 Hunninghake G, Crystal R. Pulmonary sarcoidosis - a disorder mediated by excess helper $\mathrm{T}$ lymphocyte activity at sites of disease activity. $N$ Engl J Med 1981; 305: 429-34.

34 Daniele R, Dauber J, Rossman M. Immunologic abnormalities in sarcoidosis. Ann Intern Med 1980; 92: 406-16.

35 Crystal RG, Roberts WC, Hunninghake GW, Gadek JE, Fulmer JD, Line BR. Pulmonary sarcoidosis: a disease characterised and perpetuated by activated lung T lymphocytes. Ann Intern Med 1981; 94: 73-94.

36 Goodacre RE, Bienenstock J. Reduced suppressor cell activity in intestinal lymphocytes from patients with Crohn's disease. Gastroenterology 1982; 82: 653-9.

37 Scott H, Ek J, Baklien K, Brandtzaeg P. Immunoglobulin producing cells in jejunal mucosa of children with coeliac disease on a gluten-free diet and after gluten challenge. Scand J Gastroenterol 1980; 15: 81-8.

38 Lancaster-Smith M, Joyce S, Kumar P. Immunoglobulins in the jejunal mucosa in adult coeliac disease and dermatitis herpetiformis after the reintroduction of dietary gluten. Gut 1977; 18: 887-91.

39 Ferguson A, Macdonald TT, McClure JP, Holden RJ. Cell mediated immunity to gliadin within the small intestinal mucosa in coeliac disease. Lancet 1975; 1: 895-7.

40 Howdle PD, Bullen AW, Losowsky MS. Cell mediated immunity to gluten within the small intestinal mucosa in coeliac disease. Gut 1982; 23: 115-22. 